\title{
Pengembangan Lagu Sebagai Media Pendidikan Karakter Bagi Siswa Kelas 1 SDN Purwantoro 01 Malang
}

\author{
Nuril Nuzulia \\ Dosen Universitas Islam Negeri (UIN) Maulana Malik Ibrahim Malang \\ Email: nuril.nuzulia@gmail.com
}

\begin{abstract}
Abstrak
Pendidikan karakter sendiri merupakan usaha untuk mendidik anak agar mereka dapat mengambil keputusan dengan bijak dan mempraktikkannya dalam kehidupan sehari-hari sehingga mereka dapat memberikan kontribusi yang positif kepada lingkungannya. Berbagai cara dilakukan untuk memberikan kemudahan dalam mendapatkan pendidikan karakter, salah satu caranya melalui pengembangan lagu anak.

Dalam hal ini pengembang mengembangkan lagu anak dengan mengubah lirik yang didalamnya terdapat unsur materi pelajaran. Dalam pengembangan lagu ini, pengembang menggunakan model desain pengembangan Borg \& Gall. Pengembangan ini menghasilkan lagu sebagai media pendidikan karakter siswa kelas 1 SDN Purwantoro 01 Malang.

Produk pengembangan ini diuji cobakan melalui beberapa tahap secara berurutan yakni (1) validasi ahli materi, (2) validasi ahli media, (3) validasi menurut guru, (4) uji coba lapangan. Tanggapan penilaian ahli materi terhadap pengembangan lagu adalah $86 \%$ dengan kualifikasi sangat baik. Tanggapan penilaian ahli media terhadap pengembangan lagu adalah $92 \%$ dengan kualifikasi sangat baik. Tanggapan penilaian ahli pembelajaran terhadap pengembangan lagu adalah $96 \%$ dengan kualifikasi sangat baik. Tanggapan penilaian uji coba lapangan terhadap pengembangan lagu adalah $88 \%$ dengan kualifikasi sangat baik. Dengan demikian, pengembangan lagu sebagai media pendidikan karakter ini dapat membantu meningkatkan keefektifan dan kemenarikan pembelajaran dan membantu mempermudah siswa dalam membentuk karakter islami.
\end{abstract}

Kata Kunci: Pengembangan, Lagu, Pendidikan Karakter 


\section{PENDAHULUAN}

Ada empat pilar yang menopang pembangunan bangsa, antara lain pilar ekonomi, pilar politik, pilar kesehatan, dan pilar pendidikan. Dari keempat pilar tersebut, pendidikan merupakan pilar yang paling utama di antara tiga pilar lainnya. Kuatnya pilar pendidikan akan menguatkan pilar ekonomi, pilar politik, dan pilar kesehatan.

Dalam Undang-Undang Sisdiknas Nomor 20 Tahun 2003 disebutkan bahwa pendidikan nasional berfungsi mengembangkan kemampuan dan membentuk watak serta peradaban bangsa yang bertabat dalam rangka mencerdaskan kehidupan bangsa, bertujuan untuk berkembangnya potensi peserta didik agar menjadi manusia yang beriman, dan bertakwa kepada Tuhan Yang Maha Esa, berakhlak mulia, sehat, berilmu, cakap, kreatif, mandiri, dan menjadi warga negara yang demokratis serta bertanggung jawab. ${ }^{1}$

Namun dalam praktiknya di lapangan, pendidikan di Indonesia selama ini lebih mengedepankan aspek kognitif (menjadikan anak pintar) dan mengabaikan aspek afektif (menjadikan anak berkarakter). Ada banyak bukti yang menguatkan bahwa pendidikan di Indonesia lebih mengedepankan kognitif dan mengabaikan aspek afektif (karakter) seperti banyak anak belajar dengan motivasi hanya untuk mendapatkan nilai rapor yang tinggi, semakin menjamurnya praktik menyontek pada saat ulangan dan ujian, nilai Ujian Nasional dijadikan sebagai tolak ukur keberhasilan belajar peserta didik.

Bangsa Indonesia sedang menuai akibat dari dilakukannya praktik pendidikan yang mengabaikan aspek afektif (karakter). Maka, kini dekadensi moral menimpa bangsa kita. Data hasil survei mengenai seks bebas di kalangan remaja Indonesia menunjukkan $63 \%$ remaja Indonesia telah melakukan seks bebas. Berdasarkan data dari Pusat Pengendalian Gangguan Sosial DKI Jakarta, pelajar SD, SMP, dan SMA yang trelibat tawuran mencapai 0,08 persen atau

${ }^{1}$ Anwar Arifin, Memahami Paradigma Baru Pendidikan Nasional dalam Undang-Undang SISDIKNAS (Jakarta: Depag RI, 2003), hlm. 35.

Vol. 2, No. 1, Juni 2020 
sekitar 1.318 peserta didik dari total 1.647 .835 peserta didik di DKI Jakarta, bahkan akibat dari tawuran tersebut, 26 peserta didik meninggal dunia. ${ }^{2}$

Rusaknya moral bangsa ini semakin akut tatkala korupsi, asusila, kejahatan, tindak kriminal pada semua sektor pembangunan semakin merajalela. Korupsi ternyata bukan hanya dilakukan oleh kalangan terpelajar saja, melainkan pula oleh agamawan, mulai dari kasus korupsi Gayus Tambunan hingga kasus korupsi pengadaan Al-Quran.

Untuk mengatasi problematika di atas, pendidikan di Indonesia harus diarahkan pada pembentukan karakter. Bung Karno, Bapak pendiri bangsa menegaskan bahwa " Bangsa ini harus dibangun dengan mendahulukan pembentukan karakter karena pembentukan karakter inilah yang akan membuat Indonesia menjadi bangsa yang besar, maju, dan jaya serta bermartabat. Jika pembentukan karakter tidak dilakukan, bangsa Indonesia akan menjadi bangsa kuli". ${ }^{3}$

Penelitian ini difokuskan pada persoalan pengembangan lagu untuk mendukung pelaksanaan pendidikan karakter pada anak. Pendidikan karakter pada anak mestinya diselenggarakan dengan tetap mengindahkan prinsip-prinsip penyelenggaraan pendidikan yang sesuai dengan jenjang umur dan jenjang pendidikannya. Belajar berkaitan dengan proses konsentrasi. Orang yang mampu belajar adalah orang yang mampu memusatkan perhatian.

Metode bernyanyi merupakan metode pembelajaran yang menggunakan syair-syair yang dilagukan. Biasanya syair-syair tersebut disesuaikan dengan materi-materi yang akan diajarkan. Menurut pendapat ahli, bernyanyi membuat suasana belajar menjadi riang dan bergairah sehingga perkembangan anak dapat distimulasi secara lebih optimal. ${ }^{4}$

${ }^{2}$ Dharma Kesuma dkk, Pendidikan Karakter: Kajian Teori dan Praktik di Sekolah (Bandung: Remaja Rosda Karya, 2011), hlm. 2.

${ }^{3}$ Muchlas Samani, Konsep dan Model Pendidikan Karakter (Bandung: Remaja Rosda Karya, 2011), hlm. 2.

${ }^{4}$ Muhammad Fadhillah, Desain Pembelajaran PAUD (Jogjakarta: Ar-Ruzz Media, 2012), hlm.175.

Vol. 2, No. 1, Juni 2020 
Dengan uraian tersebut memberikan gambaran bahwa kegiatan bernyanyi tidak bisa terlepas dengan dunia anak. Anak sangat suka bernyanyi sambil bertepuk tangan dan juga menari. Dengan menggunakan metode bernyanyi dalam setiap pembelajaran, anak akan mampu merangsang perkembangannya, khususnya dalam berbahasa dan berinteraksi dengan lingkungannya.

Nyanyian di sini sifatnya ialah untuk membantu anak dalam memahami materi. Jadi, nyanyiannya harus disesuaikan dengan anak usia dini. Seperti "Balonku Ada Lima" atau "Pelangi-Pelangi" yang kemudian liriknya diganti dengan materi-materi yang akan diajarkan. Manfaat-manfaat dari bernyanyi ini antara lain, anak merasa senang dalam belajar sehingga dapat menerima materi dengan mudah.

Saat ini, SDN Purwantoro 01 merupakan salah satu lembaga yang mengedepankan pengembangan karakter peserta didik melalui berbagai aktivitas belajar yang diselenggarakan. Inilah salah satu alasan penelitian ini dilaksanakan di SDN Purwantoro 01 Malang. Di samping itu, SDN Purwantoro 01 ini tergolong Sekolah Dasar yang terakreditasi A,banyak memilliki banyak prestasi dan sangat di kenal sebagai Sekolah Dasar Negeri yang unggulan di Malang. Hal ini menimbulkan asumsi bagi peneliti bahwa SDN Purwantoro 01 menerapkan pola pendidikan karakter.

Namun, permasalahannya adalah SDN Purwantoro 01 belum memiliki lagu-lagu yang mengarah pada pengembangan karakter yang ingin dikembangkan. Lagu-lagu yang digunakan selama ini adalah lagu-lagu yang digunakan secara umum yang juga terkadang tidak cocok dengan perkembangan karakter yang dikehendaki. ${ }^{5}$ Berikut persoalan yang menjadi latar belakang penulisan penelitian:

1. Belum adanya lagu-lagu yang mengarahkan pada 18 karakter

2. Belum banyak lagu yang diperdengarkan dan diajarkan langsung mengarah pada pembentukan karakter positif anak

${ }^{5}$ Hasil observasi, peneliti mendapatkan data dari Kepala Sekolah SDN Purwantoro 01, nahwa lagu-lagu yang biasa digunakan untuk mengiringi siswa beraktivitas adalah lagu-lagu anak secara umum, dan guru sering kesulitan jika mengjarkan lagu yang sesuai dengan tema pendidikan karakter yang hendak dikembangkan.

Vol. 2, No. 1, Juni 2020 
3. Tuntutan lagu sebagai media pendidikan karakter bagi anak-anak di Sekolah Dasar

Karakter berasal dari nilai tentang sesuatu. Suatu nilai yang diwujudkan dalam bentuk perilaku anak kemudian disebut dengan istilah karakter. Jadi, suatu karakter pada hakikatnya melekat dengan nilai dari perilaku tersebut. Oleh karena itu, tidak ada perilaku anak yang tidak bebas dari nilai. Sementara itu, Yahya Khan mengartikan karakter dengan sikap pribadi yang stabil dari hasil konsolidasi secara progresif dan dinamis yang mengintegrasikan antara pernyataan dan tindakan. $^{6}$

Pendidikan karakter sendiri merupakan usaha untuk mendidik anak agar mereka dapat mengambil keputusan dengan bijak dan mempraktikkannya dalam kehidupan sehari-hari sehingga mereka dapat memberikan kontribusi yang positif kepada lingkungannya. Dalam pendidikan karakter, ada tiga gagasan penting, yaitu proses transformasi nilai-nilai, ditumbuhkembangkan dalam kepribadian, dan menjadi satu dalam perilaku. ${ }^{7}$

Pendidikan karakter bertujuan untuk meningkatkan mutu penyelenggaraan dan hasil pendidikan yang mengarah pada pencapaian pembentukan karakter anak didik secara utuh, terpadu, dan seimbang. Melalui pendidikan karakter diharapkan anak didik mampu secara mandiri meningkatkan dan menggunakan pengetahuannya, mengkaji, dan menginternalisasikan serta mempersonalisasi nilai-nilai karakter yang terwujud dalam perilaku seharai-hari.

Pendidikan karakter menuntut keterlibatan semua pihak termasuk komponen-komponen yang ada dalam sistem pendidikan itu sendiri, yaitu isi kurikulum, rencana pembelajaran, proses pembelajaran, mekanisme penilaian, kualitas hubungan, pengelolaan pembelajaran, pengelolaan sekolah, pelaksanaan pengembangan diri peserta didik, pemberdayaan sarana prasarana, pembiayaan, serta etos kerja seluruh warga dan lingkungan sekolah.

6 Yahya Khan, Pendidikan Karakter Berbasis Potensi Diri; Mendongkrak Kualitas Pendidikan (Yogyakarta; Pelangi Publishing, 2010), hlm.1

${ }^{7}$ Dharma Kusuma, op,cit, hlm.5. 
Keberhasilan pendidikan karakter sangat bergantung pada ada tidaknya kesadaran, pemahaman, kepedulian, dan komitmen berbagai pihak terhadap pendidikan. Kilpatrick mengemukakan bahwa: "salah satu penyebab ketidakmampuan seseorang berperilaku baik meskipun telah memiliki pemahaman tentang kabaikan itu disebabkan karena tidak terlatih untuk melakukannya. Oleh karena itu, pendidikan karakter bagi anak sebaiknya direalisasikan melalui berbagai tindakan nyata dalam pembelajaran, jangan terlalu teoritis, dan jangan membatasi aktivitas pembelajaran, apalagi hanya terbatas di dalam kelas.

Moral understanding sebagai aspek pertama yang harus diperhatikan dalam pendidikan karakter bagi anak memiliki enam unsur, yaitu kesadaran moral, pengetahuan tentang nilai-nilai moral, penentuan sudut pandang, logika moral, keberanian mengambil keputusan, dan pengenalan diri. Keenam unsur tersebut merupakan komponen -komponen yang harus ditekankan dalam pendidikan karakter, serta diajarkan kepada peserta didik dan diintegrasikan dalam seluruh pembelajaran. ${ }^{8}$

Menurut Syamsuri Jari, menyebutkan bahwa diantara manfaat penggunaan lagu (menyanyi) dalam pembelajaran adalah sebagai berikut: 1) sarana relaksasi dengan menetralisasi denyut jantung dan gelombang otak; 2) menumbuhkan minat dan menguatkan daya tarik pembelajaran; 3) menciptakan proses pembelajaran lebih humanis dan menyenangkan; 4) sebagai jembatan dalam mengingat materi pembelajaran; 5) membangun retensi dan menyentuh emosi dan rasa estetika siswa; 6) protes internalisasi nilai yang terdapat pada materi pembelajaran; 7) mendorong motivasi belajar siswa. ${ }^{9}$

Sukses tidaknya penggunaan metode bernyanyi dalam pembelajaran sangat dipengaruhi oleh pendidik sendiri dan lagu yang dibawakannya. Bila pendidik pandai bernyanyi atau membawakan lagu, khususnya lagu anak-anak, tentu anak akan senang mendengar dan mengikutinya. Namun, bila dalam

${ }^{8}$ Mulyasa, Manajemen PAUD (Bandung: Remaja Rosda Karya, 2012), hlm. 70.

${ }^{9}$ Muhammad Fadhillah,Op,cit, hlm. 176. 
membawakan lagu sangat buruk, pasti anak akan merasa bosan dan bahkan malas mendengar, apalagi mengikutinya. Kemudian, untuk model lagunya, perlu dicari lagu yang sesuai dengan usinya. Jangan sampai lagu orang dewasa dinyanyikan oleh anak-anak. Selain tidak sesuai dengan usianya, lagu juga sulit dimengerti dan dipahami oleh anak-anak. Oleh karenanya, sebelum menggunakan metode bernyanyi dalam kegiatan pembelajaran, alangkah baiknya pilihlah lagu yang sesuai dengan karakteristik usia mereka. Supaya anak-anak dapat mengerti dan memahami dengan mudah lagu yang telah dinyanyikan, baik mudah mengikutinya maupun mudah mengambil makna-maknanya.

Selama ini telah banyak lagu-lagu yang diperdengarkan kepada anak baik untuk mengiringi aktivitas belajar mereka, maupun yang sengaja diajarkan untuk dinyanyikan secara bersama-sama maupun individu, namun tidak semua lagu tersebut mengandung muatan pendidikan karakter. Karenanya penting untuk dikembangkan lagu model pendidikan karakter, agar apa yang dilakukan pendidik dan peserta didik dapat mencapai sasaran terbentuknya karakter positif.

\section{METODE PENELITIAN}

Metode penelitian dalam pengembangan lagu sebagai media pendidikan karakter ini adalah penelitian dan pengembangan (Research and Development/ RND) karena RND merupakan metode penelitian yang digunakan untuk menghasilkan produk tertentu dan menguji keefektifan produk tersebut. ${ }^{10}$

Pengembangan lagu ini merupakan suatu produk yang dihasilkan untuk dunia pendidikan. keabsahan produk tersebut harus diuji keefektifannya agar mencapai tujuan pembelajaran dalam kurikulum. Menurut Sugiyono untuk dapat menghasilkan produk tertentu digunakan penelitian yang bersifat analisis kebutuhan dan untuk menguji keefektifan produk tersebut supaya berfungsi di masyarakat, maka diperlukan penelitian untuk menguji keefektifan produk

10 Sugiyono, Metode Penelitian Kuantitatif Kualitatif dan R\&D, (Bandung: Alfabeta, 2010), hlm 407 
tersebut. penelitian yang digunakan untuk menguji keefektifan produk tersebut adalah Research and Development.

Penelitian ini dirancang dengan menggunakan model pengembangan Borg and Gall. Siklus R\&D tersusun dalam beberapa langkah penelitian sebagai berikut:

(1) Penelitian dan pengumpulan informasi (research and information collecting)

(2) Perencanaan (planning)

(3) Pengembangan produk pendahuluan (develop preliminary from of product)

(4) Uji coba pendahuluan (preliminary field testing)

(5) Perbaikan produk utama (main product revision)

(6) Uji coba utama (main field testing)

(7) Perbaikan produk operasional (operational product revision)

(8) Uji coba operasional (operation field testing)

(9) Perbaikan produk akhir (final product revision)

(10)Diseminasi dan pendistribusian (dissemination and distribution)

Sugiyono ${ }^{11}$ membagi langkah-langkah penelitian dan pengembangan kedalam sepuluh tahap sebagai berikut (1) identifikasi masalah, (2) pengumpulan informasi, (3) desain produk, (4) validasi desain, (5) perbaikan desain, (6) uji coba produk, (7) revisi produk, (8) uji coba pemakaian, (9) revisi produk tahap akhir, dan (10) produksi massal. Langkah-langkah penelitian dan pengembangan ini dapat di gambarkan sebagai berikut:

${ }^{11}$ Sugiyono, op, cit, hlm. 409 


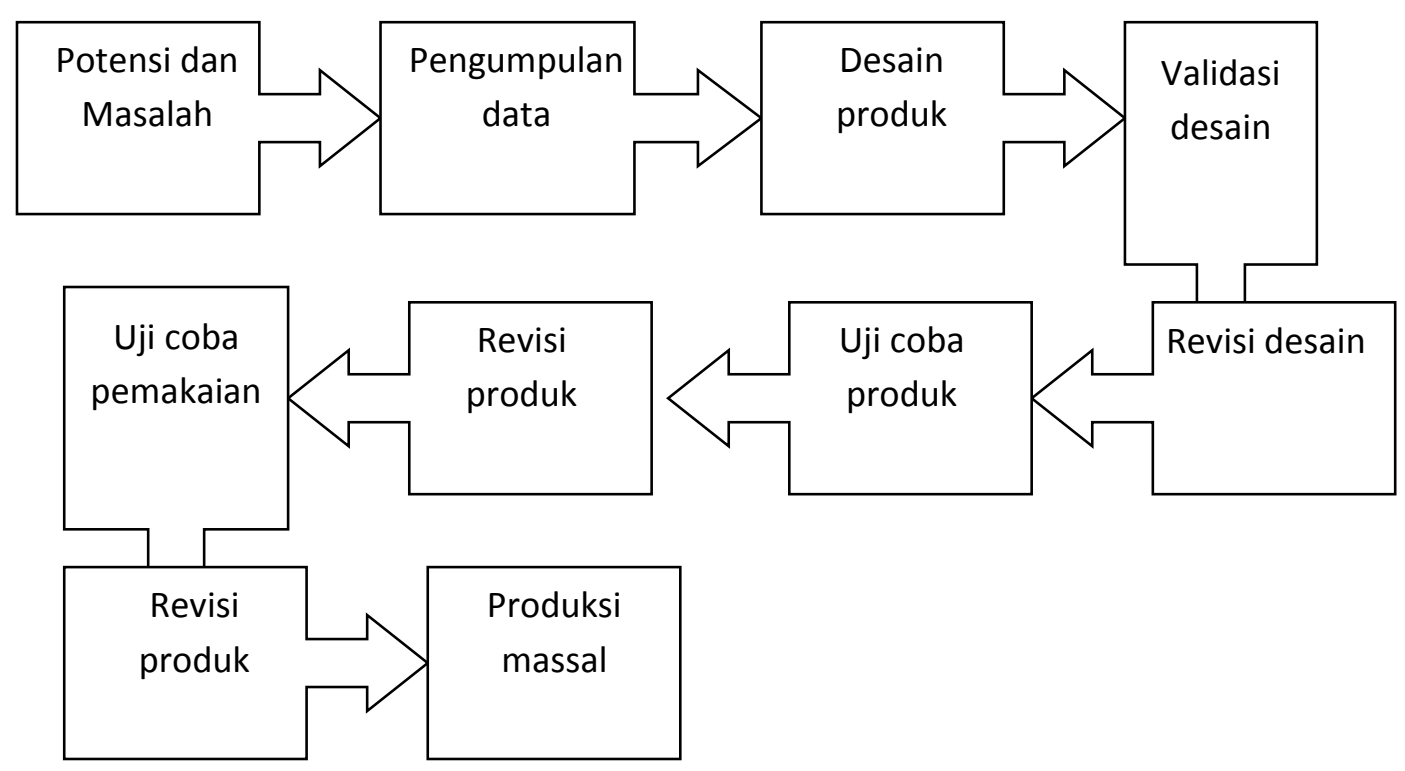

Jenis data pada penelitian pengembangan ini berupa data kuantitatif dan data kualitatif. Data kuantitatif diperoleh dari ahli materi, ahli media, guru kelas, siswa, hasil statistik sebelum dan sesudah penggunaan lagu. Sedangkan data kualitatif diperoleh dari hasil observasi dan wawancara, masukan, tanggapan, dan saran perbaikan berdasarkan hasil penilaian ahli yang diperoleh melalui wawancara dan konsultasi ahli materi, ahli media, dan guru kelas. Data tersebut digunakan untuk mengukur kualitas dari masing-masing komponen pengembangan lagu agar nantinya dapat digunakan dalam proses pendidikan karakter.

\section{HASIL PENELITIAN DAN PEMBAHASAN}

\section{Uji Ahli Materi}

\section{a. Penyajian Data}

Berikut ini akan disajikan tabel hasil jawaban yang diberikan dari ahli materi

Tabel 1

\begin{tabular}{|l|l|l|}
\hline No & Indikator & Skor \\
\hline 1. & Bahasa mudah dipahami anak & 4 \\
\hline 2. & Kata-kata mudah diucapkan & 5 \\
\hline
\end{tabular}

Vol. 2, No. 1, Juni 2020 


\begin{tabular}{|l|l|l|}
\hline 3. & Pemenggalan kalimat & 4 \\
\hline 4. & Kejelasan karakter yang disampaikan & 5 \\
\hline 5. & Tema menggambarkan dunia anak & 4 \\
\hline 6. & Cakupan materi yang disajikan & 5 \\
\hline 7. & Pengembangan indikator & 3 \\
\hline 8. & Kejelasan tujuan pembelajaran & 4 \\
\hline 9. & Kesederhanaan aransemen lagu & 4 \\
\hline 10. & Kesesuaian irama lagu & 5 \\
\hline
\end{tabular}

Berdasarkan hasil penilaian ahli materi terhadap pengembangan lagu sebagai media pendidikan karakter, maka dapat dihitung prosentase tingkat pencapaian lagu tersebut:

Karena bobot setiap pilhan adalah 2, maka prosentase $86 \%$. Setelah dikonversikan dengan tabel konversi skala 5, prosentase tingkat pencapaian $86 \%$ berada pada kualifikasi baik, sehingga lagu tidak perlu di revisi

Tabel 2. Ikhtisar Data Penilaian dan Riview Ahli Materi

\begin{tabular}{|l|l|l|}
\hline No & Saran/ Komentar \\
\hline 1. & Lirik lagunya yang lebih mudah dipahami lagi \\
\hline 2. & $\begin{array}{l}\text { Pesan moralnya kemas dengan bahasa yang lebih } \\
\text { sederhana,sehingga lagu dapat dicerna oleh anak-anak }\end{array}$ \\
\hline
\end{tabular}

Semua data hasil review, penilaian dan diskusi ahli materi dijadikan landasan untuk merevisi penyempurnaan lirik lagu sebelum diuji cobakan kepada peserta didik.

\section{b. Revisi Produk Pengembangan}

Berdasarkan hasil penilaian atau tanggapan ahli materi yang terdapat pada angket tidak perlu mendapat revisi. Akan tetapi masukan, saran, dan komentar yang disampaikan oleh ahli materi dalam angket pertanyaan terbuka, berusaha diwujudkan dengan sebaik-baiknya agar pengembangan lirik lagu ini semakin baik. 
Revisi pengembangan lagu siswa disajikan sebagai berikut:

1) Lirik Muhammad, diganti Ya Muhammad Ya Rasulullah

2) Tidak terlalu lirik, lebih baik liriknya sedikit dan diulang-ulang saja

\section{Uji Ahli Media}

\section{a. Penyajian Data}

Berikut ini akan disajikan tabel hasil jawaban yang diberikan dari ahli media

Tabel 3

\begin{tabular}{|l|l|l|}
\hline No & Indikator & Skor \\
\hline 1. & Bahasa mudah dipahami anak & 5 \\
\hline 2. & Kata-kata mudah diucapkan & 4 \\
\hline 3. & Sesuai kemampuan nafas anak & 5 \\
\hline 4. & Kejelasan karakter yang disampaikan & 5 \\
\hline 5. & $\begin{array}{l}\text { Kesesuaian dengan materi yang } \\
\text { disampaikan }\end{array}$ & 4 \\
\hline 6. & Tema sesuai dengan dunia anak & 4 \\
\hline 7. & Ambitus lagu terjangkau & 5 \\
\hline 8. & Lompatan nada terjangkau & 5 \\
\hline 9. & Kesesuaian tempo lagu & 5 \\
\hline 10. & Kesederhanaan aransemen lagu & 4 \\
\hline
\end{tabular}

Berdasarkan hasil penilaian ahli media terhadap pengembangan lagu sebagai media pendidikan karakter, maka dapat dihitung prosentase tingkat pencapaian lagu tersebut:

Karena bobot setiap pilhan adalah 2, maka prosentase 92\%. Setelah dikonversikan dengan tabel konversi skala 5, prosentase tingkat pencapaian $92 \%$ berada pada kualifikasi sangat baik, sehingga lagu tidak perlu di revisi

Adapun data kualitatif yang dihimpun dari masukan, saran dan komentar ahli media dalam pertanyaan terbuka yang berkenaan dengan lagu dipaparkan pada tabel sebagai berikut: 


\section{Tabel 4. Ikhtisar Data Penilaian dan Review Ahli Media}

\begin{tabular}{|l|l|}
\hline No & Saran/ Komentar \\
\hline 1. & $\begin{array}{l}\text { Baghround dan font huruf ditata ulang agar menarik bagi } \\
\text { pembacanya }\end{array}$ \\
\hline
\end{tabular}

Semua data hasil review, penilaian dan diskusi ahli media dijadikan landasan untuk merevisi penyempurnaan desain lagu yang berbentuk buku sebelum diuji cobakan kepada peserta didik.

\section{b. Revisi Produk Pengembangan}

Berdasarkan hasil penilaian atau tanggapan ahli media yang terdapat pada angket tidak perlu mendapat revisi. Akan tetapi masukan, saran, dan komentar yang disampaikan oleh ahli media dalam angket pertanyaan terbuka, berusaha diwujudkan dengan sebaik-baiknya agar pengembangan lagu ini semakin baik.

Revisi pengembangan lagu siswa disajikan sebagai berikut:

1) Cover buku yang semulanya berwarna sedikit gelap di ganti dengan warna yang lebih cerah

2) Tulisan yang semulanya mengunakan Times New Roman diganti dengan Comic

3) Pada setiap lirik lagu diberikan gambar animasi yang mewakilkan isi dari lagu tersebut

\section{Uji Ahli Pembelajaran (Guru)}

\section{a. Penyajian Data}

Berikut ini akan disajikan tabel hasil jawaban yang diberikan dari guru

Tabel 5

\begin{tabular}{|l|l|l|}
\hline No & Indikator & Skor \\
\hline 1. & Bahasa mudah dipahami anak & 5 \\
\hline 2. & Kata-kata mudah diucapkan & 5 \\
\hline 3. & Kejelasan karakter yang disampaikan & 5 \\
\hline 4. & Tema menggambarkan dunia anak & 5 \\
\hline 5. & Kejelasan tujuan pembelajaran & 4 \\
\hline 6. & Kesederhanaan aransemen lagu & 5 \\
\hline
\end{tabular}

Vol. 2, No. 1, Juni 2020 


\begin{tabular}{|l|l|l|}
\hline 7. & Kesesuaian irama lagu & 4 \\
\hline 8. & $\begin{array}{l}\text { Daya tarik lagu sebagai media } \\
\text { pendidikan karakter }\end{array}$ & 5 \\
\hline 9. & Antusiasme anak & 5 \\
\hline 10. & Kemampuan anak mengikuti lagu & 5 \\
\hline
\end{tabular}

Berdasarkan hasil penilaian ahli pembelajaran terhadap lagu, maka dapat dihitung prosentase tingkat pencapaian tersebut:

Karena bobot setiap pilihan adalah 2, maka prosentase 96\%. Setelah dikonversikan dengan tabel konversi skala 5, prosentase tingkat pencapaian $96 \%$ berada pada kualifikasi sangat baik, sehingga lagu tidak perlu di revisi.

Adapun data kualitatif yang dihimpun dari masukan, saran dan komentar guru dalam pertanyaan terbuka yang berkenaan dengan pengembangan lagu dipaparkan pada tabel sebagai berikut:

\section{Tabel 6. Ikhtisar Data Penilaian dan Review Guru}

\begin{tabular}{|l|l|}
\hline No & Saran/ Komentar \\
\hline 1. & Ukuran fontnya diperbesar lagi \\
\hline
\end{tabular}

Semua data hasil review, penilaian dan diskusi guru dijadikan landasan untuk merevisi penyempurnaan lagu yang berbentuk buku cetak sebelum diuji cobakan kepada peserta didik.

\section{b. Revisi Produk Pengembangan}

Berdasarkan hasil penilaian atau tanggapan guru yang terdapat pada angket tidak perlu mendapat revisi. Akan tetapi masukan, saran, dan komentar yang disampaikan oleh guru dalam angket pertanyaan terbuka, berusaha diwujudkan dengan sebaik-baiknya agar pengembangan lagu ini semakin baik.

Revisi pengembangan lagu ini disajikan sebagai berikut:

1) Ukuran fontnya yang semula Comic 14, diganti dengan arial 16 


\section{Uji Lapangan}

\section{a. Penyajian Data}

Produk pengembangan yang diserahkan kepada uji coba lapangan yang diwakili oleh satu kelas yakni kelas 1 yang berjumlah 25 siswa. Adapun data kuantitatif dari hasil penilaian uji coba lapangan sebanyak 25 orang adalah sebagaimana dipaparkan dalam tabel berikut:

\section{Tabel 7}

\begin{tabular}{|c|c|c|c|c|c|c|c|}
\hline \multirow[t]{2}{*}{ No } & \multirow[t]{2}{*}{ Kriteria } & $\bar{X}_{1}-X 30$ & \multirow{2}{*}{$\sum_{i=1}^{25} x i$} & \multirow{2}{*}{$\sum_{j=1}^{5} x j$} & \multirow[t]{2}{*}{$\mathrm{P}(\%)$} & \multirow{2}{*}{$\begin{array}{l}\text { Kriteria } \\
\text { validita } \\
\text { s }\end{array}$} & \multirow{2}{*}{$\begin{array}{l}\text { keteran } \\
\text { gan }\end{array}$} \\
\hline & & $\begin{array}{l}1,2,3,4,5,6, \\
7,8,9,10,11, \\
12,13,14,15, \\
16,17,18,19, \\
20,21,22,23, \\
24,25\end{array}$ & & & & & \\
\hline 1. & $\begin{array}{ll}\text { Bahasa mudah } \\
\text { dipahami }\end{array}$ & $\begin{array}{l}4,4,5,4,4,5, \\
5,5,5,5,5,4, \\
3,3,3,5,4,4, \\
5,5,5,5,5,5, \\
5\end{array}$ & 112 & 125 & $89 \%$ & $\begin{array}{l}\text { Sangat } \\
\text { valid }\end{array}$ & $\begin{array}{l}\text { Tidak } \\
\text { revisi }\end{array}$ \\
\hline 2. & $\begin{array}{l}\text { Kata-kata mudah } \\
\text { diucapkan }\end{array}$ & $\begin{array}{l}5,5,5,5,5,5, \\
5,5,4,3,3,4, \\
5,5,5,4,4,5, \\
5,5,5,5,5,5, \\
5\end{array}$ & 117 & 125 & $94 \%$ & $\begin{array}{l}\text { Sangat } \\
\text { valid }\end{array}$ & $\begin{array}{l}\text { Tidak } \\
\text { revisi }\end{array}$ \\
\hline 3. & $\begin{array}{l}\text { Kejelasan karakter } \\
\text { yang disampaikan }\end{array}$ & $\begin{array}{l}4,4,4,5,5,5, \\
5,5,5,5,3,3, \\
4,5,5,4,5,5, \\
5,5,4,4,4,4, \\
4\end{array}$ & 111 & 125 & $89 \%$ & $\begin{array}{l}\text { Sangat } \\
\text { valid }\end{array}$ & $\begin{array}{l}\text { Tidak } \\
\text { revisi }\end{array}$ \\
\hline 4. & $\begin{array}{l}\text { Tema } \\
\text { menggambarkan } \\
\text { dunia anak }\end{array}$ & $\begin{array}{l}5,5,4,4,4,5, \\
5,5,5,4,5,5, \\
5,4,4,5,4,5, \\
5,5,4,5,5,5, \\
5\end{array}$ & 117 & 125 & $94 \%$ & $\begin{array}{l}\text { Sangat } \\
\text { valid }\end{array}$ & $\begin{array}{l}\text { Tidak } \\
\text { revisi }\end{array}$ \\
\hline 5. & $\begin{array}{ll}\text { Kejelasan } & \text { tujuan } \\
\text { pembelajaran } & \end{array}$ & $\begin{array}{l}4,4,4,5,5,5, \\
5,5,5,5,3,3, \\
4,5,5,4,5,5, \\
5,5,4,4,4,4, \\
4\end{array}$ & 111 & 125 & $89 \%$ & $\begin{array}{l}\text { Sangat } \\
\text { valid }\end{array}$ & $\begin{array}{l}\text { Tidak } \\
\text { revisi }\end{array}$ \\
\hline 6. & $\begin{array}{l}\text { Kesederhanaan } \\
\text { aransemen lagu }\end{array}$ & $\begin{array}{l}5,5,5,5,4,3, \\
3,3,5,4,5,4, \\
4,4,4,5,4,5,\end{array}$ & 104 & 125 & $83 \%$ & Valid & $\begin{array}{l}\text { Tidak } \\
\text { revisi }\end{array}$ \\
\hline
\end{tabular}

Vol. 2, No. 1, Juni 2020 


\begin{tabular}{|c|c|c|c|c|c|c|c|}
\hline & & $\begin{array}{l}4,5,4,4,4,4, \\
4\end{array}$ & & & & & \\
\hline 7. & $\begin{array}{l}\text { Kesesuaian irama } \\
\text { lagu }\end{array}$ & $\begin{array}{l}4,4,4,4,5,5, \\
4,4,5,5,4,5, \\
5,5,3,3,4,4 \\
5,5,5,5,5,4 \\
4\end{array}$ & 110 & 125 & $88 \%$ & $\begin{array}{l}\text { Sangat } \\
\text { valid }\end{array}$ & $\begin{array}{l}\text { Tidak } \\
\text { revisi }\end{array}$ \\
\hline 8. & $\begin{array}{l}\text { Daya tarik lagu } \\
\text { sebagai } \\
\text { pendidikan karakter }\end{array}$ & $\begin{array}{l}3,3,4,4,5,5, \\
4,4,5,5,4,4, \\
4,4,5,5,5,5, \\
5,5,5,5,5,5, \\
5\end{array}$ & 113 & 125 & $90 \%$ & $\begin{array}{l}\text { Sangat } \\
\text { valid }\end{array}$ & $\begin{array}{l}\text { Tidak } \\
\text { revisi }\end{array}$ \\
\hline 9. & Antusiasme anak & $\begin{array}{l}5,5,5,4,4,5, \\
4,4,4,5,4,4, \\
4,4,5,5,5,5, \\
5,5,5,4,4,4, \\
4\end{array}$ & 112 & 125 & $89 \%$ & $\begin{array}{l}\text { Sangat } \\
\text { valid }\end{array}$ & $\begin{array}{l}\text { Tidak } \\
\text { revisi }\end{array}$ \\
\hline 10. & $\begin{array}{l}\text { Kemampuan anak } \\
\text { mengikuti lagu }\end{array}$ & $\begin{array}{l}5,5,5,5,5,4, \\
4,4,3,3,5,4, \\
4,4,3,5,5,5, \\
4,4,4,4,4,5, \\
5\end{array}$ & 108 & 125 & $86 \%$ & $\begin{array}{l}\text { Sangat } \\
\text { valid }\end{array}$ & $\begin{array}{l}\text { Tidak } \\
\text { revisi }\end{array}$ \\
\hline
\end{tabular}

Karena bobot setiap pilihan adalah 2, maka prosentase $88 \%$. Setelah dikonversikan dengan tabel konversi skala 5, prosentase tingkat pencapaian $88 \%$ berada pada kualifikasi baik, sehingga lagu tidak perlu di revisi.

\section{b. Revisi Produk Pengembangan}

Berdasarkan hasil penilaian uji coba lapangan dengan tingkat pencapaian rata-rata $88 \%$, maka pada dasarnya pengembangan lagu tidak perlu mendapat revisi. Akan tetapi masukan, saran dan komentar yang telah disampaikan oleh responden uji coba lapangan, berusaha diwujudkan dengan sebaik-baiknya sehingga akan lebih menyempurnakan lirik lagu.

Adapun revisi produk pengembangan lagu sebagai media meningkatkan pendidikan karakter, disajikan dengan mempertimbangkan saran responden yaitu dengan memberikan gambar ilustrasi yang banyak

\section{Penyajian Data Pre-Test dan Post-Test}

Tabel nilai pre test dan post test yang di dapat dari siswa kelas 1 pada saat uji coba lapangan adalah sebagai berikut: 
Tabel 8. Hasil Penilaian Uji Coba Lapangan Pada Pre- Test dan Post Test

\begin{tabular}{|l|l|l|l|}
\hline Kriteria & $\mathrm{N}$ & $\mathrm{P}(\%)$ & Keterangan \\
\hline$<75$ & 10 & $40 \%$ & Tidak tuntas \\
\hline$>75$ & 15 & $60 \%$ & Tuntas \\
\hline
\end{tabular}

Data nilai pre test (test awal) dan post test (tes akhir) tersebut selanjutnya dianalisis melalui uji t dua sampel berpasangan (paired sample t.test) dengan bantuan program komputer SPSS 17. Hasil analisis uji t dua sample berpasangan adalah sebagai berikut:

Paired Samples Statistics

\begin{tabular}{|l|l|l|l|l|}
\hline & Mean & $\mathrm{N}$ & $\begin{array}{l}\text { Std. } \\
\text { Deviation }\end{array}$ & $\begin{array}{l}\text { Std. Error } \\
\text { Mean }\end{array}$ \\
\hline Pair 1 $\begin{array}{l}\text { sebelu } \\
\text { m } \\
\text { sesuda } \\
\text { h }\end{array}$ & 68.83 & 30 & 5.363 & .979 \\
\hline
\end{tabular}

Paired Samples Correlations

\begin{tabular}{|l|l|l|l|}
\hline & $\mathrm{N}$ & Correlation & Sig. \\
\hline Pair 1 sebelum \& sesudah & 30 & .444 & .014 \\
\hline
\end{tabular}

\section{Paired Samples Test}

\begin{tabular}{|c|c|c|c|c|c|c|c|c|}
\hline & \multicolumn{5}{|c|}{ Paired Differences } & \multirow{3}{*}{ 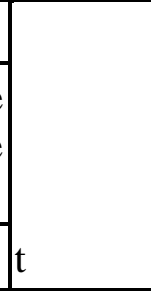 } & \multirow[b]{3}{*}{ df } & \multirow{3}{*}{$\begin{array}{l}\text { Sig. } \\
(2- \\
\text { tailed })\end{array}$} \\
\hline & \multirow[b]{2}{*}{ Mean } & \multirow{2}{*}{$\begin{array}{l}\text { Std. } \\
\text { Deviatio } \\
n\end{array}$} & \multirow{2}{*}{$\begin{array}{l}\text { Std. } \\
\text { Error } \\
\text { Mean }\end{array}$} & \multicolumn{2}{|c|}{$\begin{array}{l}95 \% \text { Confidence } \\
\text { Interval of the } \\
\text { Difference }\end{array}$} & & & \\
\hline & & & & Lower & Upper & & & \\
\hline $\begin{array}{ll}\text { Pai } & \text { sebelum } \\
\text { r } 1 & \text { - sesudah }\end{array}$ & -20.167 & 5.167 & .943 & -22.096 & -18.237 & -21.378 & 29 & .000 \\
\hline
\end{tabular}

Dalam mengambil keputusan, dapat dilihat dari signifikansi (2-tailed). Apabila $0,000 \leq 0,01=$ sangat signifikan.

Analisis Tingkat Efektifitas, Efisien, dan Kemenarikan Lagu 
Berdasarkan hasil penilaian ahli materi terhadap pengembangan lagu sebagai media pendidikan karakter menunjukkan tingkat pencapaian $86 \%$. Hal ini membuktikan bahwa pengembangan lagu ini sudah baik digunakan menurut ahli materi. Menurut ahli media menunjukkan tingkat pengembangan buku 92\%, maka hal ini membuktikan bahwa pengembangan lagu ini baik digunakan menurut ahli media. Menurut guru menunjukkan tingkat pencapaian pengembangan lagu $96 \%$. Menurut hasil uji coba lapangan menunjukkan tingkat pengembangan lagu $88 \%$. Berdasarkan skor penilaian beberapa ahli dan uji coba lapangan, maka secara umum produk pengembangan lagu ini telah memiliki kelayakan.

\section{SIMPULAN}

Berdasarkan proses pengembangan dan hasil uji coba terakhir terhadap lagu sebagai media pendidikan karakter bagi siswa kelas 1 ini dipaparkan sebagai berikut:

1. Pengembangan lagu ini menghasilkan produk berupa buku lagu untuk siswa.

2. Hasil uji coba pegembangan lagu memiliki tingkat keefektifan dan kemenarikan yang tinggi berdasarkan hasil tanggapan dan penilaian guru dan uji coba di lapangan yakni siswa kelas 1 SDN Purwantoro 01 Malang

a. Tanggapan penilaian ahli materi terhadap lagu sebagai media pendidikan karakter adalah $86 \%$ dengan kualifikasi sangat baik

b. Tanggapan penilaian ahli media terhadap lagu sebagai media pendidikan karakter adalah $92 \%$ dengan kualifikasi sangat baik.

c. Tanggapan penilaian ahli pembelajaran terhadap lagu sebagai media pendidikan karakter adalah $96 \%$ dengan kualifikasi sangat baik. 
d. Tanggapan penilaian uji coba lapangan terhadap lagu sebagai media pendidikan karakter adalah $88 \%$ dengan kualifikasi sangat baik.

3. Perolehan hasil belajar berdasarkan uji coba lapangan yang diukur menggunakan SPSS yaitu dengan merujuk Sign (2-tailed) sebesar 0,000, maka ada perbedaan yang signifikan antara rata-rata skor tes awal (pre-test) dengan tes akhir (post-test) setelah menggunakan lagu hasil pengembangan.

Dengan demikian, lagu sebagai media pendidikan karakter ini dapat dikatakan mempunyai kualitas baik. Hal ini dikarenakan penggunaan lagu ini dapat membantu meningkatkan keefektifan dan kemenarikan pembelajaran dan membantu mempermudah siswa dalam membentuk karakter islami.

\section{DAFTAR PUSTAKA}

Najib Sulhan Pendidikan Berbasis Karakter. Surabaya: PT. Jepe Press Media Utama. 2010

Hery Noer, Watak Pendidikan Islam. Jakarta: Friska Agung Insani. 2003

Undang-undang Republik Indonesia Nomor 20 Tahun 2003 Tentang Sistem Pendidikan Nasional

Trianto. Mengembangkan Model Pembelajaran Tematik. Jakarta: Prestasi Pustaka. 2010

Nurul Zuriah, Pendidikan Moral dan Budi Pekerti dalam Perspektif Perubahan. Jakarta: PT. Bumi Aksara. 2008

Subagyo. Pendidikan Kewarganegaraan. Semarang: UPT Unnes Press. 2006

Muhaimin, Modul Wawasan tentang Pengembangan Bahan Ajar. Bab V. Malang LKP2-1,. Bahan perkuliahan Pengembangan Bahan Ajar, PPS PGMI UIN Malang. 2008

Ningsih, Pengembangan Bahan Ajar Membaca Berbasis Cerita Anak untuk Siswa SMP Kelas VII, Skripsi, Program Studi Sastra Indonesia, Universitas Negeri Malang. 2012

Pramika Wardani, Pengembangan Buku Cerita Bergambar Berbasis Konservasi Lingkungan Untuk Pembelajaran Membaca Siswa SD Kelas Rendah, 
Skripsi, Program Studi Bahasa dan sastra Indonesia, Universitas Negeri Semarang. 2012

Agus Wismanto. Pengembangan Bahan Ajar Bermuatan Budi Pekerti Pada Pembelajaran Menulis Cerpen, Dosen IKIP PGRI Semarang. 2011

Supriyadi, dkk.1992. Pendidikan Bahasa Indonesia 2: Modul UT. Jakarta:Depdikbud.

Effendi, dan Mien Rumini. Materi Pokok Pengajaran Apresiasi Sastra Modul UT.Jakarta: Depdikbud. 1998

Djuanda. Pembelajaran Apresiaisi Bacaan Cerita Melalui Lokakarya di kelas V SD,Tesis, IKIP Malang. 1988

Tarigan, Dj., dkk.Kependidikan Keterampilan Berbahasa: Modul UT. Jakarta : Universitas Terbuka. 1998

Echols, John dan Hassan Shadily. Kamus Inggris Indonesia. Jakarta: Gramedia. 1993

Ngainum Naim, Character Building. Jogjakarta: Ar-Ruzz Media. 2012

Doni Koesoema, Pendidikan Karakter, Strategi Mendidik Anak di Zaman Global. Jakarta: Grasindo, 2010.

Hamid, Abdul Mursi. SDM yang Produktif: Pendekatan Al Quran dan Sains. Jakarta: Gema Insani Press. 1997

Nurcholish.Madjid Masyarakat Religius. Jakarta: Dian Rakyat. 2010

Muhamad. Ali Teologi Pluralis-Multikultural: Menghargai Kemajemukan, Menjalin Kebersamaan. Jakarta: Kompas. 2003

Baidhawy, Zakiyuddin. Ambivalensi Agama: konflik dan Nirkekerasan. Yogyakarta:Lesfi. 2002

Semiawan, Conny. Penerapan Pembelajaran pada Anak. Jakrta: PT Indeks. 2008

Rowe, Alan. Creative Intelence. Membangkitkan Potensi Inovasi dalam Diri dan Organisasi, terj. Sita Astari.Bandung: Kaifa. 2005

Sholeh, Munawar. Cita-Cita Realita Pendidikan, Pemikiran dan Aksi Pendidikan di Indonesia, Jakarta:IPE 2006

Supriadi, Dedi. Membangun Bangsa Melalui pendidikan. Bandung: Remaja Rosdakarya. 2004

Vol. 2, No. 1, Juni 2020 
Pasiak, Taufik. Manajemen Kecerdasan, emberdayakan IQ, EQ, dan SQ untuk Kesuksesan Hidup. Bandung: Mizan. 2007

Sugiyono. Metode Penelitian Kuantitatif, Kualitatif, dan $R \& D$. Bandung: Alfabeta. 2011

Walter Dick and Lou Carey.The Systematic Design of Instruction.USA: Scott, Foresman and Company. 1978

Wahid Murni dan Nur Ali. Penelitian Tindakan Kelas Pendidikan Agama dan Umum Dari Teori Menuju Disertai Contoh Hasil Penelitian.2008.Malang:UM Press. 2008

Furchan, Arief. Pengantar Penelitian Dalam Pendidikan.Yogyakarta :Pustaka Pelajar. 2007 